\title{
ETF, STOCK EXCHANGE INTERCONNECTION AND THE LOOMING PROBLEMS
}

\author{
by
}

CHIEN-CHUNG LIN*

\begin{abstract}
The growing presence of the exchange-traded fund (ETF) has been a crucial development on the investment scene since its advent in the mid-1990s. The surge of popularity for ETFs, as well as the phenomenal pace of their growth, is a fact that can be observed everywhere in stock market trading. This paper examines the legal rules, the types and workings of ETFs, and their role in promoting stock exchange interconnection.

The surge of ETFs does not come without its questions and concerns, however. With the analysis provided in this article, the potential problems, mostly notably the systemic risk showcased in the flash crash of August 24, 2015, and the inherent problem of derivative investing, are discussed. This paper concludes with a careful balancing of the benefits and perils presented by this innovative investment product.
\end{abstract}

\section{KEY WORDS}

ETF, Index-Tracking, Actively Managed ETF, Platform Connectivity, Derivative Investing and Passivity, August 24, 2015 Flash Crash

\section{INTRODUCTION}

The growing presence of the exchange-traded fund (ETF) has been a crucial development on the investment scene since its advent in the mid-1990s. Its remarkable popularity derives from two key components of its design. First, an ETF focuses on a large portfolio, which usually tracks to a well-defined index so as to diversify the credit risk posed by any one company.

chienchunglin3@gmail.com, Associate Professor of Law, National Chiao-Tung University, Taiwan \& S.J.D., University of Pennsylvania Law School. 
Second, it provides a convenient alternative for ordinary investors to buy into foreign markets when an ETF links to indexes associated with foreign stock exchanges. This link plays a similar role, functionally, to other cross listing that has occurred since the 1990s and can be viewed as part of the wave of stock exchange interconnection that has taken place more recently. Furthermore, a lower management fee and the good liquidity of an ETF also serve to attract investors.

The surge of popularity for ETFs does not come without its questions and concerns, however. Two major challenges among them are worth discussing. First, as ETFs are traded like stocks with an open quote every minute or every few seconds, a disparity between the price of an ETF and the prices of its underlying securities is possible and likely to happen regularly. In this sense, the existence of active arbitrageurs is a key element required to close the pricing gap between the underlying securities and the ETF, and thus prevents a price deviation that would ruin the ETF's tracking feature. However, the legal and market mechanisms that support arbitrage may not always be in place in all markets, and this constitutes a potential threat to an ETF's long-term success and overall stability. Second, and more fundamental for ETFs as investment instruments, the derivative nature of ETF investment slowly deteriorates the proprietary research that focuses on the new information discovery of companies. With ETFs' growing market size, this feature, in the long run, risks eroding the backbone of modern finances and endangers underlying assumptions that purport the existence of an efficient capital market. In other words, the legitimacy of financial investment faces a serious modern enemy in its derivative form - ETFs.

This paper proceeds as follows. Part 2 explains ETFs' legal design and working mechanisms, and ETFs' advantages in linking different markets in an effective and economical way. Part 3 briefly introduces the current development of the ETF market and its newest products. Part 4 discusses the challenges that the growing presence of ETF products face and the potential problems they bring to the investment scene. All of these challenges, in the view of this paper, warrant more careful scrutiny and comprehensive reassessment, as ETFs are becoming a powerful as well as an indispensable investment tool in the present day of financial market trade. Part 5 concludes. 


\section{AN ETF'S WORKING MECHANISMS: TYPES AND CONSTRUCTION}

\subsection{GENERAL BACKGROUND AND LEGAL ARCHITECTURE}

Historically, the ETF was introduced to the market in the United States in 1993. The first ETF in the United States - the SPDR Trust, which tracked Standard \& Poor's 500 Composite Stock Price Index - was structured as a unit investment trust, or UIT, and traded on the American Stock Exchange. ${ }^{1}$ The first open-end-fund ETF was introduced later, in $1996{ }^{2}$ In the first decade after its advent, investor interest in ETF products was modest. However, starting in 2004, the ETF market grew rapidly. Between 2004 and 2013, ETFs experienced an astonishing rate of growth, roughly 28 percent annually in their second decade of existence. ${ }^{3}$ By December 2012 ETF assets under management in the United States had reached \$1.34 trillion, ${ }^{4}$ and the number went up even further, to approximately \$2.1 trillion in 2015, an increase of almost 57 percent in two years. ${ }^{5}$ The pace of growth is especially stunning when compared to the total growth of mutual fund assets. Between 2001 and 2014, the overall growth of mutual fund assets was a cumulative 127 percent. ETFs grew by 2,279 percent over the same period. ${ }^{6}$

In the United States, ETFs, like their cousins the mutual funds, are structured either as (1) investment companies that are legally classified as open-end companies or as (2) UITs. ${ }^{7}$ Though similar in legal structure,

1 U.S. Securities and Exchange Commission. (2001) Concept Release: Actively Managed Exchange-Traded Funds, Investment Company Act Release No. 25258. Available from: https://www.sec.gov/rules/concept/ic-25258.htm.[Accessed 14 September 2017].

2 Ibid.

3 Ross, S. (2016) How Big Is the Global ETF Market? Investopedia. Available from: http://www.investopedia.com/articles/etfs/071216/how-big-global-etf-market-blk-stt.asp [Accessed 14 September 2017]. The global ETF market shows a similar trend. According to Ross's article for Investopedia, "Worldwide ETF assets nearly doubled between 2008 and 2010, from $\$ 715$ billion to $\$ 1.313$ trillion. The figure was $\$ 2.254$ trillion by 2013 . By the beginning of 2016, total global ETF assets were valued at \$ trillion."

4 Yoder, J. \& Howell, B. J. (2013) Actively Managed ETFs: The Past, Present, and Future. Journal of Business \& Securities Law. 13 (2), pp. 231-232.

5 Statista. (2017) ETFs - Statistics E Facts. [online] Available from: https://www.statista.com/ topics/2365/exchange-traded-funds/ [Accessed 14 September 2017].

6 Ross, S. (2016) How Big Is the Global ETF Market? Investopedia. Available from: http://www.investopedia.com/articles/etfs/071216/how-big-global-etf-market-blk-stt.asp [Accessed 14 September 2017].

7 U.S. Securities and Exchange Commission. (2013) Exchange-Traded Funds (ETFs). [online] Available from: https://www.sec.gov/answers/etf.htm. [Accessed 14 September 2017] For further information about UITs, see U.S. Securities and Exchange Commission. (2013) Unit Investment Trusts (UITS). [online] Available from: https://www.sec.gov/answers/ uit.htm [Accessed 14 September 2017]. 
an ETF differs from a traditional mutual fund in two key respects: a) ETF shares are sold on the national stock exchange for trading; b) ETFs are not redeemable for net asset value.

Regardless of the legal structure it adopts, any given ETF works in essentially the same manner. ${ }^{8}$ The basic working mechanisms are as follows: First, an ETF issues shares in blocks, known as "creation units" to institutions, which generally consist of 25,000 to 50,000 individual ETF shares. ${ }^{9}$ Second, institutional investors or brokerage houses (often referred as an "authorized participant" in an ETF context) that want to purchase creation units need to purchase them with a "portfolio deposit", which consists of a basket of securities that mirrors the composition of the ETF's portfolio or equals the aggregate net asset value (NAV) of the ETF shares in the creation unit. ${ }^{10}$ Third, after acquiring a number of creation units, those institutions use secondary markets to sell smaller blocks or individual shares to retail investors. ${ }^{11}$

In the United States, ETFs need to comply with the Investment Company Act of 1940 and a host of laws and regulations in this category. Due to the attributes of its high transparency and relatively low management risk, ETFs generally will seek from the SEC exemptions from certain provisions of the Investment Company Act of 1940. In most cases, these include exemptions from (1) the obligation of registering as an open-end investment company or an UIT, (2) the obligation to sell or redeem securities at the price of a NAV, and (3) the rule prohibiting in-kind purchases or redemptions with affiliated persons, among others. ${ }^{12}$ The review process for these applications is a lengthy one and often takes more than a year. ${ }^{13}$

\footnotetext{
8 Most ETFs are now organized as open-end management investment companies. See Yoder, J. \& Howell, B. J. (2013) Actively Managed ETFs: The Past, Present, and Future. Journal of Business $\mathcal{E}$ Securities Law. 13 (2), pp. 236.

9 Ibid, pp. 233.

10 Because ETF products often track an index (i.e. as a basket of securities or other investment targets), calculating the NAV of the underlying securities thus becomes the way to determine the value of ETF shares in the secondary market.

11 U.S. Securities and Exchange Commission. (2013) Exchange-Traded Funds (ETFs). [online] Available from: https://www.sec.gov/answers/etf.htm [Accessed 14 September 2017].

12 For more detailed discussion about the law and rules involved, see U.S. Securities and Exchange Commission. (2001) Concept Release: Actively Managed Exchange-Traded Funds, Investment Company Act Release No. 25258. Available from: https://www.sec.gov/ rules/concept/ic-25258.htm [Accessed 14 September 2017].

13 Yoder, J. \& Howell, B. J. (2013) Actively Managed ETFs: The Past, Present, and Future. Journal of Business $\mathcal{E}$ Securities Law. 13 (2), pp. 237.
} 
In the European Union, an ETF is labeled an undertaking for collective investment in transferable securities (UCITS) and needs to follow the Undertakings for Collective Investment in Transferable Securities Directive (UCITS Directive), which was adopted in 2009. ${ }^{14}$ On December 18, 2012, the European Securities and Market Authority (ESMA) published guidelines on ETFs and other UCITS issues (ESMA/2012/832) to implement the UCITS Directive. ${ }^{15}$ Primarily, the focus shifts from the formation to the actual management of ETFs, especially enhanced transparency (protection to investors) and stability (impacts to the whole system). ${ }^{16}$

Meanwhile, to facilitate cross-border sale of ETFs, an international standard-setting endeavor is also under way. For example, the International Organization of Securities Commissions published Principles for the Regulation of Exchange Traded Funds: Final Report in 2013. It carefully examines regulations and regulatory concerns across member jurisdictions, which mainly include problems of disclosure regarding ETF classification, portfolio, costs/expense, and strategies, conflicts of interest, and management of counterparty risk. The goal is to assist national regulators in addressing common issues in a more coherent way and to provide a useful policy analytical structure to attend to the ETF market's shared concerns. ${ }^{17}$

\subsection{INDEX-TRACKING FEATURE AND TYPES}

As an investment tool, initially, ETFs were designed to track the performance of a major market index or specific equity indexes;

14 Council Directive 2009/65/EC. Official Journal of European Union (2009/L 302) 13 July. Available from: http://eur-lex.europa.eu/legal-content/EN/TXT/?uri=celex:32009L0065 [Accessed 14 September 2017]. Council Directive 2014/91/EU, of the European Parliament and of the Council of July 23, 2014, Amending Directive 2009/65/EC On the Coordination of Laws, Regulations, and Administrative Provisions Relating to UCITS as Regards Depositary Functions, Remuneration Policies, and Sanctions, Official Journal of European Union (2014/L 257) 23 July. Available from: http://eur-lex.europa.eu/legal-content/EN/TXT/? uri=celex:32014L0091 [Accessed 14 September 2017]. See also, European Commission, Strengthening Global Competitiveness of EU Investment Funds. (2016) EUR-Lex. Available from: http://eur-lex.europa.eu/legal-content/EN/TXT/?uri=URISERV:mi0037 [Accessed 14 September 2017].

15 European Securities and Market Authority (2012), Guidelines for Competent Authorities and UCITS Management Companies. ESMA/2012/832EN. Available from: https://www.esma. europa.eu/sites/default/files/library/2015/11/2012832en_guidelines_on_etfs_and_other_ucits _issues.pdf [Accessed 14 September 2017]. A revised guideline was issued in 2014 (ESMA/2014/937). Available from: https://www.esma.europa.eu/sites/default/files/library/ 2015/11/esma-2014-0011-01-00_en_0.pdf [Accessed 14 September 2017].

16 Ibid

17 Board of the International Organization of Securities Commissions. (2013) Principles for the Regulation of Exchange Traded Funds: Final Report, p. 5. Available from: http://www.iosco.org/library/pubdocs/pdf/IOSCOPD414.pdf [Accessed 14 September 2017]. 
that type of ETF - an index-based ETF - continues to be the predominant type of ETF offered and sold. ${ }^{18}$ The indexes tracked can be major market indexes or other low-volume indexes alternatively. No matter whether it tracks an index in its entirety or uses representative sampling, the goal of such an ETF is to emulate an underlying index or a sample. In this sense, it reiterates the same logic established when Vanguard led the mutual fund industry revolution by introducing the first index fund-First Index Investment Trust - in 1976. ${ }^{19}$

An index-based ETF can track a foreign index by forming a basket of foreign securities in its portfolio. For investors, investing in an ETF that tracks a foreign index provides an easy alternative to investing directly in another country, especially when they want to hedge their investment risk in a particular country but do not equip with the adequate resource in choosing any particular company in that foreign country nor easy access to that market. The ability to access foreign markets is a powerful investment tool. Obviously it broadens the range of investment possibilities, which means there will be more good-quality companies that an investor can choose from and better portfolio management as a result. Furthermore, an index-based ETF diversifies national risk (high-growth countries versus low-growth countries) as well as currency exposure (when US dollars move inversely relative to most of the foreign currencies). This hedging function enables a better composition in terms of risk management. In this regard, an index-based ETF, like other index investing, allows investors to invest in a less-familiar country and opens the door for less-sophisticated investors to make overseas investments. This broadening horizon of investment in turn benefits both capable businesses (cheaper capital) and lay investors (more investment opportunity).

Nowadays, ETFs have evolved into a variety of investment tools. Targets of ETF investment have expanded from equity to include fixed-income products, commodities, currency, and real estate. ${ }^{20}$ Specialty funds came on the scene at a later stage. Leveraged funds and inverse funds

18 U.S. Securities and Exchange Commission. (2012). Investor Bulletin: Exchange-Traded Funds (ETFs). SEC. Available from: https://www.sec.gov/investor/alerts/etfs.pdf [Accessed 14 September 2017].

19 Bogle, J. C. (2006) The First Index Mutual Fund: A History of Vanguard Index Trust and the Vanguard Index Strategy. Vanguard. Available from: https:/www.vanguard.com/ bogle_site/lib/sp19970401.html [Accessed 14 September 2017].

20 Ashworth, W. (2017) 6 Popular ETF Types for Your Portfolio. Investopedia. Available from: http://www.investopedia.com/articles/exchangetradedfunds/11/ten-popular-etf-types.asp [Accessed 14 September 2017]. 
are synthesis funds that provide larger or inverse risk/return ratio, which caters to particular types of investors. ${ }^{21}$ Actively managed ETFs, which seek to outperform their index-tracking peers, also started to gain traction and created some uncertainty regarding their regulation, as they work against the original passive nature of the index-based design.

\subsection{PLATFORM CONNECTIVITY, PRICE DISPARITY, AND ARBITRAGE}

The essential innovation of an ETF is that it possesses two key features of the mutual fund: investing in a basket of targets instead of some individual companies and having the ability to cross national borders or trading platforms easily. By this means, investors achieve better default risk allocation by spreading their financial resources across a group of companies in different markets. ${ }^{22}$ In other words, having a diversified investment with a purchasing focus that stipulates a group criterion is one competitive advantage of the mutual fund. As the ETF inherits this feature, a similar effect can be obtained with lower cost compared to directly purchasing stock from companies in the basket or investment portfolio.

However, portfolio diversification and the ability to access foreign companies/markets easily are not enough to account for the ETF's popularity, as a similar level of diversification can be easily obtained by ordinary mutual fund investment, too. The additional factors in ETFs' rise in popularity include the fact that ETFs enjoy a better degree of liquidity, similar to most stock traded on the stock exchange, and consequently more accurate valuation as a result. Because ETFs are traded on a stock exchange and have intra-day quotes, a continuous quoting system makes ETF pricing more efficient and more reflective of all related intra-day activities and thus more efficient in terms of effective trading as a result. What is more, compared to traditional index-tracking mutual funds, a lower management fee has helped ETFs gain their foothold in a competitive asset management market. In other words, compared

21 Ibid.

22 Generally, default risk means the chance that an individual or a company will be unable to pay its debt or meet other monetary obligations. The reasons that default occurs can be attributed to two main groups of reasons: one, mismanagement of the debtor's own finances or, two, a change in the macro-environment that cannot be attributed directly to the debtor. Compared with investing in single target, spreading one's investment across as many targets as possible reduces the overall default risk because mismanagement, it may be assumed, is not likely to happen across the board and all at once. 
to a mutual fund, investing in foreign ETFs generally gives investors a lower management fee and more instant execution.

Combining the best of two worlds does not come without a price, however. Conceptually, an ETF is a separate security with different issuers. It only reflects the economic value of the underlying securities when all things proceed ideally (or put differently, efficiently). When that happens, the ETF's price should accurately reflect the real-time economic value of the underlying securities or other investment it represents. By its legal structure, an ETF is an independent investment that does not legally link back to those underlying securities or equal ownership of those securities. Since the ETF and the underlying securities are two different securities traded in different venues or time zones, different trading scenarios or local market conditions may have two sets of supply and demand and thus two prices. In other words, price disparity is always likely, in theory as well as in practice. ${ }^{23}$

To facilitate better price equivalence, or to eliminate a tracking difference in ETF industry jargon, a well-functioning ETF needs a group of effective arbitrageurs (mostly large brokers or institutions that are willing to assume the role of market maker) for two purposes. First, arbitrageurs, when buying low and selling high, provide much-needed liquidity to the ETF market, which is critical to retail investors and the local market as well. Second, arbitrage activities help close the price gap with underlying securities by buying or selling an ETF when an ETF's price goes under or over the underlying securities.

Although arbitrageurs play a critical role in the ETF market, the incentive mechanism or economic return for arbitrageurs is, ironically, not very clear. When too few participants join in this arbitrage, a growing difference in pricing is likely to be the outcome. When this happens, more arbitrageurs enter to take advantage of the larger profit opportunity in arbitraging. In this sense, presumably, the concern over a suboptimal level of arbitrageur participation might in fact be self-correcting. However, actual fine-tuning in the real world is still an issue for further observation, especially in markets where ETF block participation is low.

${ }^{23}$ This price disparity is sometimes called "tracking difference". See, Board of the International Organization of Securities Commissions. (2013) Principles for the Regulation of Exchange Traded Funds: Final Report. p. 4. Available from: http://www.iosco.org/library/pubdocs/pdf/ IOSCOPD414.pdf [Accessed 14 September 2017]. 


\section{CURRENT STATUS REVIEWED}

The rising popularity of ETF products is one conspicuous development in the world of investment. A closer look at the data and the market trends allows us to forecast the prospects and challenges for ETFs that lie ahead.

\subsection{HISTORICAL DATAAND CURRENT STATUS: GIANTS AT THE GATE}

As discussed earlier, the ETF market started to take off in 2004 and has grown exponentially in the United States ever since. Between 2004 and 2013, ETFs grew at the astonishing rate of roughly 28 percent annually. ${ }^{24}$ By 2008 ETF assets under management in the United States was $\$ 498$ billion. By 2012 the number was up to $\$ 1.21$ trillion.1 The number reached USD $\$ 2.47$ trillion by December 2016, a fivefold increase in eight years. ${ }^{25}$

The global market shows a similar trend. ETFs have accrued over USD\$3 trillion assets under management as of the end of 2016, across 4,808 funds, ${ }^{26}$ and are traded on over 60 exchanges. ${ }^{27}$ In Europe, assets under management in European ETFs amounted to USD\$143 billion in 2008, \$331 billion in 2012, and $\$ 542$ billion at the end of December $2016 .{ }^{28}$ The average annual growth rate in ETF assets exceeded 40 percent from 2006 to 2015, outpacing the already astonishing US market. ${ }^{29}$

The top five ETF product providers, ranked by global assets, are iShares issued by BlackRock (market share 36.8 percent, assets under management reached USD $\$ 1,304$ billion in August 2016), Vanguard (market share 18.2 percent, assets under management USD $\$ 647$ billion), SPDR ETFs (market share 15.2 percent, assets under management USD\$538 billion),

24 Ross, S. (2016) How Big Is the Global ETF Market? Investopedia. Available from: http://www.investopedia.com/articles/etfs/071216/how-big-global-etf-market-blk-stt.asp [Accessed 14 September 2017].

25 Statista. (2017) ETFs - Statistics E Facts. [online] Available from: https://www.statista.com/ topics/2365/exchange-traded-funds/ [Accessed 14 September 2017].

26 ETFGI. ETFGI.com. Available from: http://etfgi.com/index/cookie [Accessed 14 September 2017].

${ }^{27}$ Hassine, M. (2016) European ETF Market Outlook for 2016. Lyxor Asset Management. Available from: http://www.lyxor.com/uploads/tx_bilyxornews/European_ETF_Market_ Outlook_for_2016.pdf [Accessed 14 September 2017].

28 ETFGI. ETFGI.com. Available from: http://etfgi.com/index/cookie [Accessed 14 September 2017].

29 Hassine, M. (2016) European ETF market outlook for 2016. Lyxor Asset Management. Available from: http://www.lyxor.com/uploads/tx_bilyxornews/European_ETF_Market_ Outlook_for_2016.pdf [Accessed 14 September 2017]. 
and much smaller PowerShares and Nomura AM. ${ }^{30}$ BlackRock and Vanguard, two leading ETF managers, marked a record year in 2016, as the former attracted $\$ 140$ billion to its iShares business and the latter gathered in $\$ 93$ billion. ${ }^{31}$ Notably, the ETF market is rather concentrated, as more than 70 percent of the market is dominated by the top three powerhouses.

Equally important is that the overall trading volume of ETFs exceeded that of stock in 2016. More specifically, according to Bloomberg, only 3 of the 15 most heavily traded securities in 2016 were individual stocks, citing data compiled by Credit Suisse Group AG. ${ }^{32}$ Not only a challenge to traditional mutual funds and stocks, observers also see ETFs as an ideal vehicle to replace certain derivatives, as low-cost ETFs are used to substitute for fully funded futures or credit default swaps. ${ }^{33}$

In the meantime, the landscape inside the EFT industry is not static. As types of ETFs proliferate, variations other than the traditional index-tracking ETF have emerged and created new dynamics. This trend also poses tough questions for the future of ETFs.

\subsection{GLOBALIZATION OF INVESTMENT AND MARKET CONNECTIVITY}

Having more international investment opportunity, provided first by mutual funds and later by foreign ETFs and other derivative investments that connect to international trading venues, poses both opportunities

30 ETFGI. ETFGI.com. Available from: http://etfgi.com/index/cookie [Accessed 14 September 2017].

31 Willmer, S. \& Stein, C. (2017) BlackRock Sees Record Flows into Low-cost ETFs as Passive Rules. Bloomberg. Available from: https:/www.bloomberg.com/news/articles/2017-01-13/ blackrock-fourth-quarter-profit-rose-on-etf-inflows-lower-costs [Accessed 14 September 2017]. Basically, buying ETFs still incurs costs and other expenses. Because an ETF is traded through a stock exchange, placing a buy or sell order through a broker will generally incur a trading fee (mostly commission). Moreover, ETF providers have an expense ratio for their ETF, which is used to collect money from investors to cover an ETF's expenses. The industry average ETF expense ratio is 0.28 percent. See Vanguard Group (2016), ETF Fees and Minimums, Available from: https://investor.vanguard.com/etf/fees [Accessed 14 September 2017].

32 Burger, D. (2017) Stocks Are No Longer the Most Actively Traded Securities in Stock Markets. Bloomberg. Available from: https://www.bloomberg.com/news/articles/2017-01-12/ stock-exchanges-turn-into-etf-exchanges-as-passive-rules-all [Accessed 14 September 2017].

33 Ernst \& Young. (2016) Global ETF Survey 2016 - Integrated Innovation: The Key to Sustainable Growth, p. 9. Available from: http://www.ey.com/Publication/vwLUAssets/ey-integratedinnovation-the-key-to-sustainable-growth-global-etf-survey-2016/\$File/ey-integratedinnovation-the-key-to-sustainable-growth-global-etf-survey-2016.pdf

[Accessed 14 September 2017]. 
and threats to the traditional wisdom of both regulation and industry policy. Following are some of the often-mentioned ones:

1. Capital outflow and loss of domestic investment. For developing countries, more foreign stock ETFs, as they represent more access to foreign markets, may accelerate capital outflow and weaken capital accumulation when local capital seeks a safer place to invest. A similar but reverse concern relates to mature markets, too. In mature markets or developed countries, when facing lower or sluggish growth, easy access to other markets might mean more money outflow into a foreign market in search of a hoped-for higher return. Therefore, this concern may be exaggerated in its essence. In the abstract realm where theories work out as conceived, the outflow of capital should be to some extent offset by the inflow that seeks to diversify in the opposite direction, and thus reach a balance of inflow and outflow of capital that corresponds to each market's strength and weakness.

2. Regulatory challenges. At the product level, much product-level scrutiny and collaboration have been provided across different markets, especially in markets where regional integration has started. ${ }^{34}$ The challenge is to apply a well-defined set of rules to a universe of products that may use similar names but function much differently from each other, or vice versa. Also, when ETF products evolve and increase in variety, the rules must be tailored to deal with the different types of risk they engender. To what extent the increased regulatory burden can be justified by the increased investment choices is a perpetual question of balancing that most regulatory agencies need to consider. However, in a financial world where global competition is common, and the speed of moving money to any part of the world is swift, how to achieve the proper level of regulation (or alternatively, delegation of regulatory duty

34 A similar concept can be found in financial "passporting" in the European Economic Area. For a useful introduction on European passporting, see Bank of England (2017), Passporting. [online] Available from: http://www.bankofengland.co.uk/pra/Pages/ authorisations/passporting/default.aspx [Accessed 14 September 2017]; BBA (2017), Brexit Quick Brief: What Is "Passporting" and Why Does It Matter? [online] Available from: https://www.bba.org.uk/wp-content/uploads/2016/12/webversion-BQB-3-1.pdf [Accessed 14 September 2017]. For product-level coordination in ASEAN countries, see e.g. PricewaterhouseCoopers (2015), Funds Passport Regimes in Asia Pacific: Taxing Issues, Available from: https://www.pwc.com/sg/en/asset-management/assets/funds-passportregimes-in-asia-pacific.pdf [Accessed 14 September 2017]. 
to foreign regulators who oversee other major markets) may be a more difficult question to answer than ever, as no single regulator can answer that question alone.

3. International cooperation. A linked securities market as we see today is a fact that no regulator can deny. Contrary to the existing reality, however, the corresponding regulatory net falls far short of the anticipated extent. Currently, securities regulation is mostly a domestic matter, which is subject to each country or market's regulation. Although there is a striking similarity in the substance of these regulations, a coordinated or joint enforcement mechanism is dangerously absent when dealing with some global securities market issues such as a flash crash that might hit all markets in a matter of hours. This threat, in the form of systemic risk, rises as market connectedness becomes denser. In other words, when markets are more connected, as we see now, a systemic risk of global proportion looms ever larger, and the traditional national border can no longer serve as a firewall. In this regard, enhanced institutionalized international effort should be high on the agenda for the years to come. ${ }^{35}$

Indeed, a more efficient international capital flow is, in its essence, a democratization and liberalization of investment. This is a trend that can be traced back to the 1970s when it was first introduced by John Bogle, the founder of the largest mutual fund company in the United States: Vanguard. ${ }^{36}$ The philosophy of index investment has proven successful in the last half century. This trend of success has become particularly spectacular since the 2008 financial crisis and is expected to continue for a certain period of time. ${ }^{37}$ However, some critics raise questions about the essence of ETF investment and caution that past success does not guarantee worry-free future success. This concern will be addressed in more detail in subsection 4.1 .

35 For example, the International Organization of Securities Commissions and Financial Stability Board.

36 More generally, see Bogle, J. C. (1994) Bogle on Mutual Funds: New Perspectives for the Intelligent Investor. New York, McGraw-Hill.

37 Citing the results of a survey it conducted, PricewaterhouseCoopers predicts ETF asset will at least double and reach $\$ 5$ trillion or more by 2020. PricewaterhouseCoopers. (2015) ETF 2020: Preparing for a New Horizon, p. 8. Available from: https://www.pwc.com/jg/en/ publications/etf-2020-exchange-traded-funds-pwc.pdf [Accessed 14 September 2017]. 


\subsection{ACTIVELY MANAGED ETF}

The array of ETF products, due to the pressure from competition and the desire for growth, has evolved into a more complex buffet of offerings beyond mere index tracking. Leveraged, inverse, commodity, fix-income, or hybrid ETFs are among the new entrants offering variations of their index-tracking predecessors. From a business viewpoint, it is natural and understandable that sponsors need to differentiate and expand their product lines to cater to different investor needs when a market reaches maturity. Outside the United States, a similar trend is seen in Europe as more innovative offerings are expected to come with a growing number of investors favoring a strategic deployment. ${ }^{38}$

Among them, actively managed ETFs capture much attention, especially from a regulatory perspective. Supporters, as well as critics, have debated the proper legal rules for regulating actively managed ETFs since their first appearance in the United States in 2008, seven years after the SEC issued a Concept Release in 2001. ${ }^{39}$ The concerns related to the actively managed ETF, as discussed in the 2001 Concept Release, include (1) its relatively lower transparency (due to the fact that an actively managed ETF may need to change its portfolio more often compared to a traditional index-tracking ETF); (2) a disclosure rule that can balance investor confidence/information and an ETF's trading advantage; (3) whether an actively managed ETF can ensure that the portfolio securities are sufficiently liquid to permit effective arbitrage. ${ }^{40}$

In 2008 the SEC finally agreed to issue a first exemptive order permitting an ETF to pursue active investment strategies. In a series of similar exemptive orders, the SEC basically demanded an actively managed ETF to disclose a daily portfolio and make sales and marketing disclosures as premises for its exemptive order. ${ }^{41}$ Similar to the earlier pattern

${ }_{38}$ Morningstar Manager Research. (2014) A Guided Tour of the European ETF Marketplace, p. 2. Available from: http://media.morningstar.com/eu/Events/ETFEU/ETFEU14/ETF_Industry_ Report_4Nov.pdf [Accessed 14 September 2017].

39 Yoder, J. Howell, B. J. (2013) Actively Managed ETFs: The Past, Present, and Future. Journal of Business \& Securities Law. 13 (2), p. 240; U.S. Securities and Exchange Commission. (2001) Concept Release: Actively Managed Exchange-Traded Funds, Investment Company Act Release No. 25258. Available from: https://www.sec.gov/rules/concept/ic-25258.htm [Accessed 14 September 2017].

40 U.S. Securities and Exchange Commission. (2001) Concept Release: Actively Managed Exchange-Traded Funds, Investment Company Act Release No. 25258. Available from: https://www.sec.gov/rules/concept/ic-25258.htm [Accessed 14 September 2017].

${ }^{41}$ Ibid. 
for ordinary ETFs, these exemptive orders' conditions set a precedent for other companies to follow when seeking an exemptive order for a new actively managed ETF. In other words, the SEC's response to the actively managed ETF is neutral, emphasizing the need for enhanced transparency and a demand for more public information for investors. ${ }^{42}$

The emergence of actively managed ETFs characterizes a trend of continuous product proliferation that makes perfect business logic, and it also reflects the ever-expanding appetite for investment even after the devastating financial crisis of $2007-2008 .{ }^{43}$ However, if one looks at these innovations from a careful theoretical perspective, the advent of actively managed ETFs also represents a clear reversal of the traditional index-tracking feature common to most ETFs. This reversal thus poses a question about its very design concept as well as the regulatory approach that the SEC applied to other ETFs earlier. Further discussion on the future of actively managed ETFs and their possible impact is provided in subsection 4.2 .

\section{LOOMING CHALLENGES}

As mentioned earlier, when tracking a foreign index, an ETF gains much of its popularity from two key features: its capability to diversify investment by putting money in a large group of targets, on the one hand, and the convenience of investing in a foreign market directly on the local exchange, on the other hand. These two features, to a large extent, contribute to its desirability. However, some consequences of these features present problems, especially as the ETF market expands and slowly changes the contours of securities trading.

${ }^{42}$ A similar approach is followed in the new rule of October 2016. See U.S. Securities and Exchange Commission (2016), News Release: SEC Adopts Rules to Modernize Information Reported by Funds, Require Liquidity Risk Management Programs, and Permit Swing Pricing [online], p. 240, fn. 62. Available from: https://www.sec.gov/news/press release/2016-215.html. [Accessed 14 September 2017].

43 Actively managed ETFs, despite the publicity they have received and the heated discussion they have sparked, currently represent only 1 percent of global ETF assets under management. Optimistic observers view the situation as an opportunity for growth. See Ernst \& Young. (2016) Global ETF Survey 2016 - Integrated Innovation: The Key to Sustainable Growth, p. 9. Available from: http://www.ey.com/Publication/vwLUAssets/eyintegrated-innovation-the-key-to-sustainable-growth-global-etf-survey-2016/\$File/eyintegrated-innovation-the-key-to-sustainable-growth-global-etf-survey-2016.pdf [Accessed 14 September 2017] 


\subsection{THE PROBLEM OF DERIVATIVE INVESTING 4.1.1 PASSIVITY}

One primary challenge of ETFs is the problem of derivative investing. The threat posed by derivative investing is not to ETFs directly but the very concept of investment itself. Due to the feature of index tracking, ETFs, in reality, piggyback on certain larger criteria, namely the index compilation criteria, which are responsible for choosing an ETF's investment targets. In other words, as an investment vehicle, an ETF delegates the job of picking target companies to invest into the index compiler with the hope that the index is broad and well-selected enough to diversify default risk, avoid selection bias, and enjoy an average (or little above average) return. If so accomplished, it can reduce its investigation cost and attract more retail investors by lowering its fee. However, when more money is poured according to a broad preexisting criterion, be it a market or any industry, choosing a company to invest in without looking into the details of that company would become the norm. When this happens on a large enough scale, the capital market does not have a governance function and cannot discern good companies from bad ones.

When most of the funds are working in this abstracted fashion, fund managers then naturally have fewer incentives to scrutinize each company composing a bundle. Therefore, the corporate governance function of investors (especially of institutional investors) is weakened substantially. The loss of market discipline from financial investors, in the long run, will slowly deteriorate the monitoring role of large investors. This is especially true when all large investors, through all kinds of funds or ETFs, only hold a small stake in any one company, which is too small to justify any serious intervention, and when the number of targets receiving investment is several dozen or even hundreds.

The long-term impact may be complicated and profound. The expanding ETF market not only distorts the traditional price-finding function of investment; it also threatens the traditional corporate governance function and the hierarchy of shareholder vis-à-vis management, which are fundamental building blocks in modern corporate governance: capital providers, namely investors, monitor and discipline managers as the final line of defense in the corporate world. When the trend toward derivative investing such as index mutual funds and index-tracking ETFs continues 
to spread and becomes a stable majority, the consequent threats for financial markets and corporate governance will grow even larger and become that much harder to reverse.

\subsubsection{SELECTION BIAS AND MARKET VOLATILITY}

Index selection has an overt preference for companies that are already large, without paying equal attention to emerging ones that are worth noticing. It can be argued that the job of fostering young emerging companies should be shouldered by other vehicles such as venture capital, angel investors, or even incubators. However, as a clear prevalence for collective investment tools such as ETFs takes root, the long-term effect of the selection bias led by ETFs becomes worrisome to many. It is not clear to what extent actively managed ETFs or new indexes might mitigate this problem, but surely companies at the burgeoning stage deserve close attention as the ETF market booms exponentially.

Another related problem brought on by preponderating ETF products is market volatility. As more and more money is poured into ETFs and other index-tracking products, the movement of certain indexes can trigger market panic more easily than previously expected. One example of precipitous, unforeseen sell-off was the market flash crash of August 24, 2015.

On August 24, 2015, Standard \& Poor's 500 index opened at 1965.15 and within minutes fell to a low of 1867.01, a 5 percent decline. The Dow shed more than 1000 points that day in early trading, about 6.6 percent at its worst point. ${ }^{44}$ Later the Standard \& Poor 500 bounced back and closed at 1893.21. This sudden crash was triggered by a sell-off on August 20 (closing at 2035.73, a 43.88 point loss from the previous day) and August 21 (closing at 1970.89), leaving investors wary heading into the weekend. One thing that triggered the crash on Monday, August 24, 2015, was the decline of 8.5 percent that morning on the Shanghai stock exchange. ${ }^{45}$ However, as all markets quickly stabilized, the actual reasons for this crash, as well its recovery, are still subject to debate.

44 Long, H. (2015) The Stock Market Drop... By The Numbers. CNN Money, August 24. Available from: http://money.cnn.com/2015/08/24/investing/stocks-market-crash-by-thenumbers/ [Accessed 14 September 2017].

45 Mitchell, C. (2016) The Two Biggest Flash Crashes of 2015. Investopedia, January 11. Available from: http://www.investopedia.com/articles/investing/011116/two-biggest-flashcrashes-2015.asp [Accessed 14 September 2017]. 


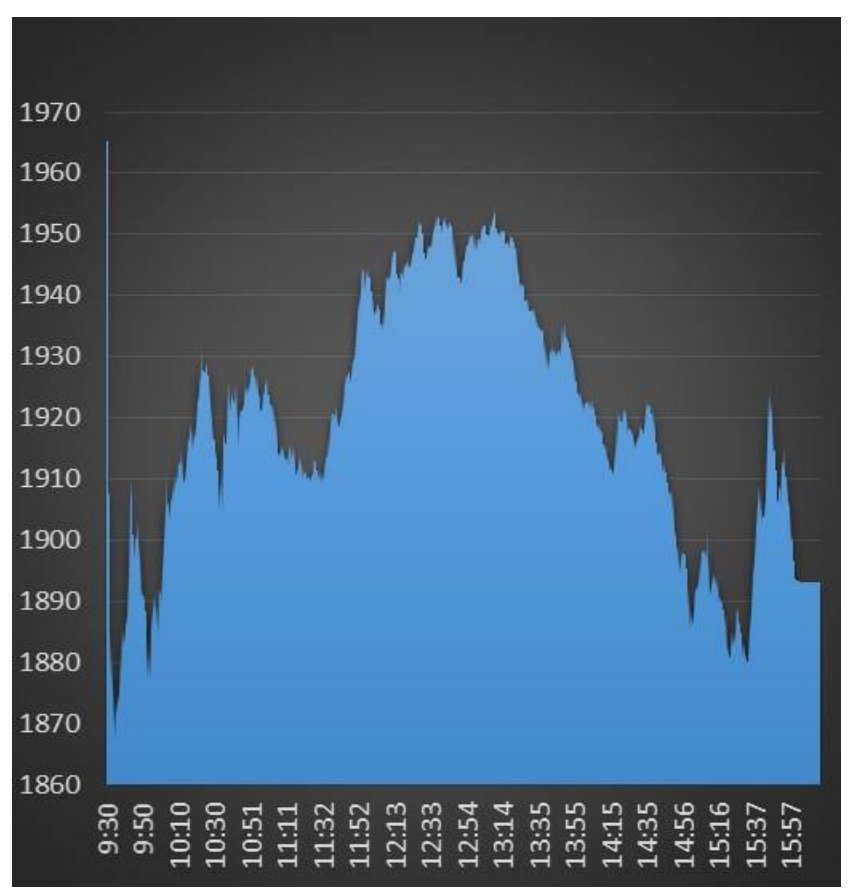

Figure 1: Standard \& Poor's 500 price movement, August 24, 2015.

The $y$-axis is scaled by stock market points, and the $x$-axis is scaled by (mostly) twenty-minute increments. ${ }^{46}$

This single event illustrates several crucial facts about market structure when dominated by ETFs and other index-tracking investment vehicles. As most observers felt confused about the exact reasons for the crash and its similarly odd recovery, it seems that (a) the interconnectivity of markets around the globe shows a clear domino effect: as one market falls, it leads to another falling, as was seen on August 24, 2015, in the UK and Germany markets. ${ }^{47}$ This connectivity spreads unrest to other markets even when other markets face no similar threat or reason for decline. Furthermore, (b) ETFs, like other index-tracking investment tools, face a more severe challenge than do ordinary stocks in such a situation when some of the composing stocks have a problem. In the market crash of August 24, 2015 , because of the lack of bids, many stocks in the index composition were delayed in opening. ${ }^{48}$ It left many ETFs' prices unable to be determined

46 Data Source: Bloomberg.

47 Ro, S. \& Udland, M. (2015) Market Mayhem. Business Insider, August 24. Available from: http://www.businessinsider.com/us-markets-sell-off-aug-24-2015-2015-8

[Accessed 14 September 2017]. 
and thus triggered further unrest. This unrest led to further decline in the ETFs' prices. $^{49}$

\subsubsection{MARKET SIZE}

The sheer increase of market size by itself also constitutes a potential threat to overall market stability. From the case of Standard \& Poor's 500 crash on August 24, 2015, it becomes obvious that ETF products are vulnerable to market volatility by their very nature. Namely, when one or more companies in the index or portfolio cannot get a quote for some reason, that delay will jeopardize timely quoting more widely and then disrupt the entire trading of the ETF, even if the companies that stop trading only constitute a tiny portion of the entire portfolio. Further, a chain reaction of markets, time differences, and the complexity in stock bundling make it more difficult to arrive at an informed and timely decision. In a financial trading world like this, a mistaken drop and recovery as was witnessed on August 24, 2015, surprised and disturbed many investors and market watchers and is likely to occur again at some point in the future..$^{50}$

48 Pisani, B. (2015) What Happened During the Aug 24 "Flash Crash"? CNBC.com, September 25. Available from: http://www.cnbc.com/2015/09/25/what-happened-duringthe-aug-24-flash-crash.html [Accessed 14 September 2017]. Pisani reports that "[o]nly about half of SEP 500 stocks were opened on NYSE by 9:35 a.m."; in addition, "there were 1,278 trading halts for 471 different ETFs and stocks. Because of this, it was not possible to calculate the value of many ETFs, or hedge or trade ETFs and stocks at a 'correct' price." This occurred because high-speed traders use models that shut down their systems when they detect extreme pricing anomalies. See also, Egan, M. (2015) Trading Was Halted 1,200 Times. CNN Money, August 24. Available from: http://money.cnn.com/2015/08/24/ investing/stocks-markets-selloff-circuit-breakers-1200-times/ [Accessed 14 September 2017].

49 Dieterich, C. (2015) The Great ETF Debacle Explained: The Stock Market Slide on August 24 Led to ETF Prices Falling More Sharply Than the Stocks They Owned. Barron's Asia, September 5. Available from: http://www.barrons.com/articles/the-great-etf-debacleexplained-1441434195.[Accessed 14 September 2017]. Dieterich explains that "when the S\&P 500 fell as much as $5.3 \%$ in the opening minutes of trading, the $\$ 65$ billion iShares Core SEP 500 ETF fell as much as $26 \%$, some 20 percentage points below its fair value. Disorderly trading affected big ETFs from every major provider: The \$18 billion Vanguard Dividend Appreciation ETF and the $\$ 12$ billion SPDR SEP Dividend plunged $38 \%$ apiece, while the PowerShares SEP 500 Low Volatility ETF fell as much as $46 \%$ before clawing back an hour after markets opened." See also, Nadig, D. (2016) Understanding ETF "Flash Crashes." ETF.com, August 24. Available from: http://www.etf.com/sections/blog/understanding-etf-flash-crashes?no paging=1 [Accessed 14 September 2017]. For his explanation of the flash crash, Nadig uses the Guggenheim Equal Weight S\&P 500 ETF to exemplify how ETFs suffered deeper drops than their underlying indexes; to illustrate the disparity, Nadig points out that the Guggenheim Equal Weight S\&P 500 ETF was "trading below \$50 when 'fair value' for the underlying stocks never dropped below $\$ 71 . "$

50 The word mistaken is aptly used to describe the drop because no one actually knows what caused the August 24 drop. As all major stocks are linked to some extent today, once the fall goes beyond some tipping point, a run can start. At this point, the ability of a market to selfcorrect may no longer function once panic spreads and the drop acts like an avalanche. The decline may only end once the markets cool off. As analysts later realized, the drop may be baseless, and the recovery can come on as quickly as the drop. 


\subsection{ACTIVELY MANAGED ETF: A WAY BACK TO THE OLD PROBLEM?}

As the ETF market evolves, the desire for ETFs to compete against each emerges. For those index-tracking products, more indexes are created, and slowly they become a universe of their own. These newly created indexes, in most cases, are tailored to meet ETF companies' promotion needs. For alternative ETF products, actively managed ETFs have also come on the scene to attract investors who want to outperform the market and garner greater profits through better stock-picking skill. Two approaches, seemingly complementary to each other from the perspective of product diversification, are possibly contradictory in their essence. The divergence in direction poses a question about the validity of the philosophy under which the ETF industry traditionally presented itself.

The emergence of actively managed ETFs, though still proportionately small in terms of total value, thus begs a theoretical question. ${ }^{51}$ Leaving concerns such as transparency, exemption, and performance of actively managed ETFs aside, on its face, an actively managed ETF and other synthetic products are in a clear opposite position to ordinary index-tracking products, which get their appeal from their simplicity. If this observation holds, the rise of actively managed ETFs and other synthetic products may bring about a fall in popularity for traditional index-tracking ETFs, by the operation of logic. However, the real-world situation is confusingly contradictory, as a rise in both products types is occurring. This oddity is still a debated phenomenon, and its possible future development is not settled by consensus. But as the growth speed of ETFs presents an undisputed trend, the proper governance of ETF products and the corresponding regulatory approach thus becomes an unavoidable challenge, in the short term and in the long run.

51 PricewaterhouseCoopers. (2015) ETF 2020: Preparing for a New Horizon, p. 19. Available from: https://www.pwc.com/jg/en/publications/etf-2020-exchange-traded-funds-pwc.pdf [Accessed 14 September 2017]. The report's authors write, "The vast majority of U.S. ETF assets, approximately $99 \%$ of them, are currently in passively managed index products. Active ETFs accumulated approximately \$16 billion of assets under management (AMU) between 2008 and mid-2014." A similar estimation says that as of 2015, out of the asset tied to ETFs in the U.S. market, which was more than USD\$2 trillion, less than 1 percent of it was tied to actively managed ETFs. More up-to-date data can be found in ETF.com. ETF.com. (2017) Active Management ETF Overview. [online] Available from: http://www.etf.com/channels/ active-management-etfs [Accessed 14 September 2017]. 


\section{CONCLUSION}

The growing ETF market around the world brings about much greater interconnectivity across multiple trading platforms and markets. Notably, the proliferation of ETF products allows smaller investors to reach out to the global market more easily in a safer, or more hedged, way. From the perspective of product design, ETFs successfully bypass, at least supplement to, the traditional approach of dual listing, and consequently its high transactional costs. ETFs allow investing in a foreign market directly, which used to be the privilege of larger or institutional investors, and create a third route of access to other products and trading platforms. This newly created route, more importantly, by reaching out to smaller investors and linking global markets, also increases the depth of the market and thus makes the overall market more efficient and stable, if all trading activities follow an ordinary course or we consider its effects only at the micro level. With its help, the current financial market becomes a more connected and less partitioned one.

In addition to offering easier access to foreign investment opportunities and investment targets, the index-tracking feature of most ETF products also possesses advantages over traditional stocks. The ability to link multiple stocks in an index also contributes to a lower volatility, which attracts investors. Moreover, it provides better liquidity and more price efficiency. In short, it revolutionizes the landscape of investment. The ever-growing volume of assets under management confirms this trend.

However, despite their distinct advantage and proven commercial success, the development or proliferation of ETF products across the board also faces severe challenges. One key problem arises from the fact that ETF investment is, in its essence, a derivative one. Derivative investment with its passive nature, in the long run, endangers the functional dynamics of a securities market and companies that receive investment. This change in dynamics will gradually but steadily reshape the structure of traditional investment concepts and, more fundamentally, the ways that companies respond to capital market demands. In addition, connectivity also poses a threat to the stability of linked markets, as a baseless drop may happen suddenly, followed by a quick and similarly unaccountable recovery.

The bottom line is that ETFs are a powerful instrument, one that has transformed the landscape of financial investment. It liberalizes the job 
of stock picking and enables global investment, which traditionally had been the preserve of sophisticated professionals or large institutional investors. Although challenges and uncertainties lie ahead, the immense power of financial innovation still opens up a lot of possibilities to all involved, be they regulatory agencies, the investment community, or curious individuals.

\section{LIST OF REFERENCES}

[1] Ashworth, W. (2017) 6 Popular ETF Types for Your Portfolio. Investopedia. Available from: http://www.investopedia.com/articles/exchangetradedfunds/11/ten-popular-etftypes.asp [Accessed 14 September 2017].

[2] Bank of England. (2017) Passporting. [online] Available from: http://www.bank ofengland.co.uk/pra/Pages/authorisations/passporting/default.aspx

[Accessed 14 September 2017].

[3] BBA. (2017) Brexit Quick Brief: What Is "Passporting" and Why Does It Matter? [online] Available from: https://www.bba.org.uk/wp-content/uploads/2016/12/webversion-BQB -3-1.pdf [Accessed 14 September 2017].

[4] Board of the International Organization of Securities Commissions. (2013) Principles for the Regulation of Exchange Traded Funds: Final Report. Available from: http://www.iosco.org/library/pubdocs/pdf/IOSCOPD414.pdf

[Accessed 14 September 2017].

[5] Bogle, J. C. (1994) Bogle on Mutual Funds: New Perspectives for the Intelligent Investor. New York, McGraw-Hill.

[6] Bogle, J. C. (2006) The First Index Mutual Fund: A History of Vanguard Index Trust and the Vanguard Index Strategy. Vanguard. Available from: https://www.vanguard. com/bogle_site/lib/sp19970401.html [Accessed 14 September 2017].

[7] Burger, D. (2017) Stocks Are No Longer the Most Actively Traded Securities in Stock Markets. Bloomberg. Available from: https://www.bloomberg.com/news/articles/201701-12/stock-exchanges-turn-into-etf-exchanges-as-passive-rules-all

[Accessed 14 September 2017].

[8] Council Directive 2009/65/EC. Official Journal of European Union (2009/L 302) 13 July. Available from: http://eur-lex.europa.eu/legal-content/EN/TXT/?uri=celex:32009L0065 [Accessed 14 September 2017]. 
[9] Council Directive 2014/91/EU of the European Parliament and of the Council of July 23, 2014, Amending Directive 2009/65/EC On the Coordination of Laws, Regulations, and Administrative Provisions Relating to UCITS as Regards Depositary Functions, Remuneration Policies, and Sanctions, Official Journal of European Union (2014/L 257) 23 July. Available from: http://eur-lex.europa.eu/legal-content/EN/TXT/?uri=celex: 32014L0091 [Accessed 14 September 2017].

[10] Dieterich, C. (2015) The Great ETF Debacle Explained: The Stock Market Slide on Aug. 24 Led to ETF Prices Falling More Sharply Than the Stocks They Owned. Barron's Asia, September 5. Available from: http://www.barrons.com/articles/the-greatetf-debacle- explained-1441434195 [Accessed 14 September 2017]

[11] Egan, M. (2015) Trading Was Halted 1,200 Times. CNN Money, August 24. Available from: http://money.cnn.com/2015/08/24/investing/stocks-markets-selloff-circuitbreakers-1200-times/ [Accessed 14 September 2017].

[12] ETF.com. ETF.com. (2017) Active Management ETF Overview. [online] Available from: http://www.etf.com/channels/active-management-etfs

[Accessed 14 September 2017].

[13] ETFGI.com. Available from: http://etfgi.com/index/cookie [Accessed 14 September 2017].

[14] Ernst \& Young. (2016) Global ETF Survey 2016- Integrated Innovation: The Key to Sustainable Growth. Available from: http://www.ey.com/Publication/vwLUAssets/eyintegrated-innovation-the-key-to-sustainable-growth-global-etf-survey- 2016/\$File/eyintegrated-innovation-the-key-to-sustainable-growth-global-etf-survey-2016.pdf

[Accessed 14 September 2017]

[15] European Commission, Strengthening Global Competitiveness of EU Investment Funds. (2016) EUR-Lex. Available from: http://eur-lex.europa.eu/legal-content/EN/TXT/ ?uri=URISERV:mi0037 [Accessed 14 September 2017].

[16] European Securities and Market Authority (2012), Guidelines for Competent Authorities and UCITS Management Companies. ESMA/2012/832EN. Available from: https://www.esma.europa.eu/sites/default/files/library/2015/11/2012-832en_guidelines_ on_etfs_and_other_ucits_issues.pdf [Accessed 14 September 2017].

[17] European Securities and Market Authority (2014), Guidelines for Competent Authorities and UCITS Management Companies. ESMA/2014/937. Available from: https://www.esma. europa.eu/sites/default/files/library/2015/11/esma-2014-0011-01-00_en_0.pdf [Accessed 14 September 2017]. 
[18] Hassine, M. (2016) European ETF Market Outlook for 2016. Lyxor Asset Management. Available from: http://www.lyxor.com/uploads/tx_bilyxornews/European_ETF_ Market_Outlook_for_2016.pdf [Accessed 14 September 2017].

[19] Long, H. (2015) The Stock Market Drop... By The Numbers. CNN Money, August 24. Available from: http://money.cnn.com/2015/08/24/investing/stocks-market-crash-bythe-numbers/ [Accessed 14 September 2017].

[20] Mitchell, C. (2016) The Two Biggest Flash Crashes of 2015. Investopedia, January 11. Available from: http://www.investopedia.com/articles/investing/011116/two-biggestflash-crashes-2015.asp [Accessed 14 September 2017].

[21] Morningstar Manager Research. (2014) A Guided Tour of the European ETF Marketplace. Available from: http://media.morningstar.com/eu/Events/ETFEU/ETFEU14/ETF_ Industry_Report_4Nov.pdf [Accessed 14 September 2017].

[22] Nadig, D. (2016) Understanding ETF “Flash Crashes." ETF.com, August 24. Available from: http://www.etf.com/sections/blog/understanding-etf-flash-crashes?nopaging=1 [Accessed 14 September 2017].

[23] Pisani, B. (2015) What Happened During the Aug 24 "Flash Crash"? CNBC.com, September 25. Available from: http://www.cnbc.com/2015/09/25/what-happenedduring-the-aug-24-flash-crash.html [Accessed 14 September 2017]

[24] PricewaterhouseCoopers. (2015) ETF 2020: Preparing for a New Horizon. Available from: $\quad$ https://www.pwc.com/jg/en/publications/etf-2020-exchange-traded-fundspwc.pdf [Accessed 14 September 2017].

[25] PricewaterhouseCoopers. (2015) Funds Passport Regimes in Asia Pacific: Taxing Issues, Available from: https://www.pwc.com/sg/en/asset-management/assets/fundspassport-regimes-in-asia-pacific.pdf [Accessed 14 September 2017].

[26] Ro, S. \& Udland, M. (2015) Market Mayhem. Business Insider, August 24. Available from: http://www.businessinsider.com/us-markets-sell-off-aug-24-2015-2015-8 [Accessed 14 September 2017].

[27] Ross, S. (2016) How Big Is the Global ETF Market? Investopedia. Available from: http://www.investopedia.com/articles/etfs/071216/how-big-global-etf-market-blkstt.asp [Accessed 14 September 2017].

[28] Statista. (2017) ETFs -Statistics \& Facts. [online] Available from: https://www.statista. com/topics/2365/exchange-traded-funds/ [Accessed 14 September 2017]. 
[29] U.S. Securities and Exchange Commission. (2001) Concept Release: Actively Managed Exchange-Traded Funds, Investment Company Act Release No. 25258. Available from: https://www.sec.gov/rules/concept/ic-25258.htm [Accessed 14 September 2017].

[30] U.S. Securities and Exchange Commission. (2013) Exchange-Traded Funds (ETFs). [online] Available from: https://www.sec.gov/answers/etf.htm [Accessed 14 September 2017].

[31] U.S. Securities and Exchange Commission. (2013) Unit Investment Trusts (UITS). [online] Available from: https://www.sec.gov/answers/uit.htm [Accessed 14 September 2017].

[32] U.S. Securities and Exchange Commission. (2016) News Release: SEC Adopts Rules to Modernize Information Reported By Funds, Require Liquidity Risk Management Programs, and Permit Swing Pricing. [online] Available from: https://www.sec.gov/ news/pressrelease/2016-215.html [Accessed 14 September 2017].

[33] Vanguard Group. (2016) ETF Fees and Minimums, Available from: https://investor. vanguard.com/etf/fees [Accessed 14 September 2017].

[34] Willmer, S. \& Stein, C. (2017) BlackRock Sees Record Flows into Low-cost ETFs as Passive Rules. Bloomberg. Available from: https://www.bloomberg.com/news/ articles/2017-01-13/blackrock-fourth-quarter-profit-rose-on-etf-inflows-lower-costs [Accessed 14 September 2017].

[35] Yoder, J. \& Howell, B. J. (2013) Actively Managed ETFs: The Past, Present, and Future. Journal of Business \& Securities Law. 13 (2), pp. 231-257. 